\title{
SCHOENBAUM REVISITED: LIMITING THE SCOPE OF ANTIFRAUD PROTECTION IN AN INTERNATIONALIZED SECURITIES MARKETPLACE
}

\author{
Donald C. LANGevoort*
}

\section{INTRODUCTION}

In 1968, the Second Circuit decided Schoenbaum v. Firstbrook, ${ }^{1}$ a doctrinally significant case for two reasons. The initial panel decision found, among other things, that the allegedly fraudulent mismanagement of a foreign company had sufficient effects in the United States to trigger the assertion of U.S. subject matter jurisdiction. ${ }^{2}$ This formulation stands today as the most influential of the so-called "effects" standards for extraterritorial application of the federal securities law. In turn, the full court sitting en banc further determined that the sort of misconduct involved (a sale of securities engineered by company insiders in a conflict of interest setting) constituted a deceptive act falling substantively within the scope of Rule 10b-5. ${ }^{3}$ This holding engendered a long series of cases that developed the use of Rule 10b5 for cases with undisclosed breaches of fiduciary duty by corporate management impacting the purchase or sale of a security. ${ }^{4}$

Schoenbaum is separately well remembered for both the extraterritorial and substantive holdings. What has been lost in time is the connection between them, a connection that poses a latent puzzle in this era of rapid internationalization. That is, to what extent can or should the U.S. securities laws be construed to reach misconduct that is not classic securities fraud, when some critical mass of affected investors in the enterprise in question are based in the United States or when some of the alleged misconduct occurred

Copyright (C) 1992 by Law and Contemporary Problems

* Lee S. and Charles A. Speir Professor of Law, Vanderbilt University.

The author would like to thank Hal Maier, Bob Hillman, Jim Cox, Patrick Daugherty, and all the participants at the Law and Contemporary Problems Conference for their helpful comments on earlier drafts, and Wilder Lee for his research assistance.

1. 405 F2d 200 (2d Cir 1968) ("Schoenbaum"), rev'd in part en banc, 405 F2d 215 (2d Cir 1968)

("Schoenbaum en banc").

2. 405 F2d at 208.

3. $405 \mathrm{~F} 2 \mathrm{~d}$ at 219 . The extraterritoriality holding was not reconsidered by the full court.

4. This notwithstanding the Supreme Court's attempted pruning in the name of federalism in Santa Fe Industries $v$ Green, 430 US 462 (1977) (discussed in detail at text accompanying notes 42-48). 
here? This is more than an abstract exercise. To date, most of the internationalization debate has gone to the question of harmonizing disclosure and procedural requirements among various legal systems (for example, Regulation $S^{5}$ and the recently enacted multi-jurisdictional disclosure system ${ }^{6}$ ), and to cooperative enforcement efforts for instances of multinational misconduct. Most of the extraterritorial fraud cases so far have been relatively easy ones substantively, involving clear allegations of corruption. But it will only be a matter of time before cases arise that more visibly involve standards of fiduciary responsibility and similar conduct restraints where the potential for implicit conflicts in legal cultures is strong. ${ }^{7}$ The line between regulatory and fraud rules is really quite blurred.

This article argues that as a result of the forces creating an internationalized securities marketplace, the prevailing extraterritoriality doctrine has become both useless and problematic. If greater restraint is the appropriate posture (and I believe that it is), then the question is whether that doctrine can reasonably be reformulated in a way that is less troubling. My conclusions are mixed. While some useful revisionism is possible simply by borrowing from some of the ways that courts have begun to limit the domestic substantive scope of the antifraud provisions, there are conceptual limits on what this alone can accomplish, at least with respect to Schoenbaum's effects test, in light of the strongly pro-investor purposes historically associated with the antifraud prohibitions. A more radical posture of restraint is possible, but only by abandoning some assumptions that heretofore have served as doctrinal givens.

II

\section{INTERNATIONALIZATION AND EXTRATERRITORIALITY}

\section{A. The Methodological Anomaly}

To understand the consequences of our current posture toward extraterritorial application of U.S. law, we must first appreciate the curious nature of the methodology employed by the courts in this area. Schoenbaum itself was fairly straightforward: after concluding that Congress was essentially silent on the subject, the court determined as a matter of plain statutory interpretation that U.S. law should cover the sort of misconduct involved because of its threat to domestic interests. ${ }^{8}$ Soon thereafter,

5. 17 CFR $\S 230.901-04$ (1991) (providing safe harbors for sales of securities in off-shore transactions with respect to $\S 5$ of the Securities Act of 1933).

6. Securities and Exchange Commission, Multijurisdictional Disclosure and Modifications to the Current Registration and Reporting System for Canadian Issuers, Securities Act Rel No 6902, 56 Fed Reg 30,036 (July 1, 1991) (amending 17 CFR $\$ 200$ et seq, effective July 1, 1991) (allowing Canadian companies to register securities using disclosures mandated by Canadian law).

7. By implicit conflicts, I mean a situation where one country has adopted a rule that another would not see as justified, although there is no inconsistency between the two in terms of placing actors in a position of having to violate one law in order to comply with the other.

8. See Schoenbaum, 405 F2d at 206-09. The courts often rationalize their result by referring to congressional intent, but with so little in legislative history to work with, virtually any conclusion can 
however, the courts (particularly the Second Circuit) moved to something of a two-step analysis. They asked first-by reference to principles of international law-whether the United States could reach the conduct in question (that is, whether it had the "jurisdiction to prescribe").9 Here, the principal authority invoked was the Restatement (Second) of the Foreign Relations Law of the United States ("Restatement"), ${ }^{10}$ which in turn set forth two alternative tests. One permitted the exercise of jurisdiction where there were significant effects in the United States from foreign conduct, the other where there was significant conduct here that produced harm abroad. The courts recognized, however, that ultimately the question of subject matter jurisdiction is still a policy concern, meaning that there is no reason to believe that Congress intended the scope of the federal securities law to be identical with the outer limits of its jurisdiction to prescribe. Hence, the second step resorts to traditional interpretive techniques (such as reference to statutory purpose and cost-benefit considerations).

In more recent cases, however, this bifurcation has disappeared as courts have articulated the Restatement's effects and conduct standards as "the tests" for extraterritorial jurisdiction, while at the same time accepting that extraterritoriality is still essentially a matter of federal common law in the guise of statutory interpretation." 1 What, then, is the prevailing methodology? While there are many possibilities (including doctrinal confusion), the kindest is that the courts are invoking principles of international law as devices to aid in the resolution of the interpretive question, an approach that makes sense to the extent that the Restatement and related materials exhibit a useful sensitivity to questions arising when activity falls in the realm of multiple legal regimes.

This article will proceed on the assumption that this methodological description is both accurate and apt, and that the question of extraterritoriality remains essentially a policy question to be answered by the courts. ${ }^{12}$ References to principles of international law, then, are not meant in

be so justified. For much the same reason, I will not dwell on $\S 30$ (b) of the Securities Exchange Act, which was read in Schoenbaum as a meaningless jurisdictional limitation with respect to the antifraud provisions. Id at 207-08. For a recent argument that Congress was not really silent, and that evidence of legislative intent is much more useful than the courts have given it credit for, see Margaret V. Sachs, The International Reach of Rule 10b-5: The Myth of Congressional Silence, $28 \mathrm{Colum} \mathrm{J}$ Transnatl L 677 (1990). There is, of course, the separate requirement that some jurisdictional means relating to interstate commerce be employed by the defendant, a standard that has substantial limiting potential depending on its construction. See note 65.

9. The best illustration of this two-step approach is Leasco Data Processing Equip. Corp. v Maxwell, 468 F2d 1326, 1334-35 (2d Cir 1972).

10. The American Law Institute replaced the Second Restatement with the Third Restatement in May of 1986. See Restatement (Third) of the Foreign Relations Law of the United States (1987); see also notes 26-28 and accompanying text.

11. See, for example, Alfadda v Fenn, 935 F2d 475, 478 (2d Cir 1991), cert denied, 112 S Cı 638 (1991); MCG Inc. v Great Western Energy Corp., 896 F2d 170, 174 (5th Cir 1990); AVC Nederland B.V. v Atrium Investment Partnership, 740 F2d 148, 154-55 (2d Cir 1984); Continental Grain (Australia) Pty., Ltd. $v$ Pacific Oilseeds Inc., 592 F2d 409, $416-17$ n12 (8th Cir 1979).

12. The most recent decision by the Supreme Court in this area is EEOC v Arabian U.S. Oil Co., $111 \mathrm{~S} \mathrm{Ct} 1227$ (1991). This decision is rhetorically striking, emphasizing that congressional intent is 
their intended sense as limitations on the jurisdiction to prescribe, but rather for their heuristic role in helping think through the policy dilemmas posed in this setting.

\section{B. The Prevailing Tests and Their Weaknesses}

The rapid internationalization of the securities markets has been driven by a number of factors: communications and information technology, schemes of regulation that can be avoided by off-shore activity, and the like. ${ }^{13}$ As a result, four essential features of the global marketplace are present that will give rise to an increasing number of extraterritoriality problems. First, trading markets in various countries are losing monopoly status over particular securities; increasingly, the securities of U.S. companies are also traded abroad, and those of foreign companies here. Second, issuers, promoters, brokers, and advisers have ready access to investors in other countries without having to set foot therein, even when there is no preestablished market. Third, with the growth of information intermediaries, investors can seek out foreign investments that are not even marketed domestically, by buying and selling stocks abroad. Fourth, investors can readily establish or participate in foreign-based investment entities. This last point is particularly important for our purposes. With the rapid institutionalization of the securities markets, investment decisions are increasingly being made on behalf of pools of money, the beneficial ownership of which is neither confined to, nor necessarily even dominated by, the residents of any single country. ${ }^{14}$

When we turn to the traditional approaches used by the courts in the United States to determine the extent to which the antifraud provisions of the federal securities laws should apply extraterritorially, we see what an awkward fit they offer in this sort of globalized environment. 15

the ultimate focus of extraterritoriality methodology and reaffirming the presumption against extraterritoriality absent express evidence to the contrary. The Court did not find the requisite congressional intent to extend the reach of Title VII to the "employment practices of United States employers who employ United States citizens abroad." Id at 1229-35. However, the decision dealt with an issue that is quite different from those considered in the securities cases, since it did not involve a situation with a direct effect in the United States or domestic conduct. Both conduct and impact were foreign. Arabian U.S. Oil was legislatively overruled by $\& 109$ of the Civil Rights Act of 1991, Pub L No 102-166, 105 Stat 1077 (1991), to be codified at 43 USC $\$ 2000 \mathrm{e}-1$.

13. For a sampling of views on the structure of the internationalized markets, see Norman $S$ Poser, International Securities Regulation: London's "Big Bang" and the European Securities Market (Little Brown, 1991); Office of Technology Assessment, Trading Around the Clock: Global Securities Markets and Information Technology (July 1990); compare Donald C. Langevoort, Information Technology and the Structure of Securities Regulation, 98 Harv L Rev 747, 761-63 (1985).

14. There are legal limitations. The SEC, for example, has discouraged foreign investment companies from marketing their product in the United States except through the creation of "mirror" U.S.-based companies. See Michael E. Sherman, Restrictions on the Activities of Foreign Investment Companies in the U.S., 5 InSights, No 5 at 30 (1991).

15. I am hardly alone in this perception. See, for example, Robert S. Karmel, The Second Circuit's Role in Expanding the SEC's Jurisdiction Abroad, 65 St John's L Rev 743 (1991); Barbara S. Thomas, Extraterritorial Application of United States Securities Laws: The Need for a Balanced Policy, 7 J Corp L 189 (1982); Charles J. Johnson, Jr., Application of Federal Securities Laws to International Securities Transactions, in Howard T. Sprow, special ed, Financing the International Capital Markets: The Seventh Annual Fordham 
1. The Effects Test. The most compelling justification for the extraterritorial application of U.S. law is to reach conduct abroad that produces substantial adverse effects in the United States. This is what Schoenbaum was all about: the Second Circuit decided that the undisclosed corporate mismanagement of a Canadian company involving securities that were traded on the U.S. Stock Exchange (as well as in Toronto) created a sufficiently direct harm to U.S. investor interests to constitute a violation of Rule 10b-5.

While it is hard to quarrel with the abstract principle underlying the effects test, its potential breadth in an internationalized securities marketplace is remarkable. While the courts have not yet clearly articulated the sort of adverse effect that must be alleged (in part because of the dearth of cases), a fair reading of the cases suggests that it is the presence of significant deception (that is, ill-informed investor decisions) occurring in the United States. ${ }^{16}$ And at the risk of slight overstatement, in a technologically-linked investment marketplace-especially in an environment characterized by multiple trading and highly institutionalized investing-virtually every investment-related action anywhere in the world will promptly produce significant distortions of investment decisions in every other developed country in a way that could justify the exercise of subject-matter jurisdiction. Imagine in the near future, for example, a world-wide investment database that contains comprehensive information on a wide variety of investment opportunities, formatted in a way that permits useful scanning and comparison. Issuers and financial intermediaries could offer data for inclusion, as a means of informing the marketplace and (presumably) attracting capital. Almost by definition, this system would be "offering" securities in every country in which it was accessible; surely, data introduced into the system would be treated as "in connection with" the purchase or sale of a security. As a result, misinformation in the system would have the requisite effects not only in the United States but virtually everywhere else.

To the extent that the misinformation in the system involved "core" securities fraud-that is, intentionally deceptive misrepresentation designed to line the pockets of the issuer or some broker or investment adviser-there is little problem in the conclusion that multiple countries could seek to exercise both subject matter and personal jurisdiction. Core fraud is considered an evil in all civilized countries, and only the most opportunistic of

Corporate Law Institute 57 (Law \& Business, 1980); Stevan Sandberg, The Extraterritorial Reach of U.S. Economic Regulation: The Case of Securities Law, 17 Harv Intl L J 315 (1976); Note, Predictability and Comity: Toward Common Principles of Extraterritorial Jurisdiction, 98 Harv L Rev 1310 (1985).

16. The mere fact that the fraud causes financial harm to an U.S.-based investor is not enough. Indeed, in Leasco Data Processing Equipment Corp., 468 F2d 1326, the Second Circuit indicated that a fraud on a U.S. company involving a foreign securities purchase would not be actionable absent some level of fraudulent misconduct in the United States. Id at 1333-34. This could be read to suggest that absent such domestic misconduct, Rule 10b-5 applies only where the securities transaction in question occurs here (that is, that it is the tainted purchase or sale that is the crucial effect). But that is inconsistent with Schoenbaum, since there, the sale clearly occurred in Canada. The only reconciliation-completely consistent with the policy underlying Rule 10b-5-is to focus on the investor decision as the important effect. In Schoenbaum, as we shall discuss, that was the failure of the U.S. investors to take protective action. See also IIT v Comfeld, $619 \mathrm{~F} 2 \mathrm{~d}$ 909, $923 \mathrm{n} 17$ (2d Cir 1980). 
jurisdictions close their eyes to it. But anyone well familiar with Rule 10b-5 and the related antifraud provisions of the federal securities laws knows that the scope of these laws goes well beyond core fraud. Schoenbaum's application of Rule 10b-5 to insider self-dealing, even in the absence of any investor trading, is one example; our abandonment of privity, ${ }^{17}$ reliance, ${ }^{18}$ and (in some respects) scienter ${ }^{19}$ requirements in certain cases may be others. Take, for example, a situation where a Belgian company is in the process of negotiating a merger with a Dutch company. In response to a press inquiry, it falsely denies that negotiations are underway in order to preserve their confidentiality and so maximize the chance that shareholders will receive the expected value of the transaction. In the United States, that company would be liable, and pecuniary damages would be extensive: even investors not aware of the misrepresentation would probably be able to recover. Without revisiting the basic controversies underlying these doctrinal choices, suffice it to say that they give rise to a broad scope of jurisdiction about which reasonable regulatory minds may readily differ. ${ }^{20}$ Yet U.S. standards become de facto standards for worldwide behavior when applied to foreign investments because of their availability to U.S. investors.

The effects test is especially potent if it reaches foreign-based fraud on foreign-based entities simply because those entities have U.S.-based investors. With worldwide investing, the incidence of indirect-but nonetheless significant-domestic pecuniary harm from essentially foreign misconduct increases. To date, the courts have tended to draw a distinction between claims of subject matter jurisdiction for those foreign entities that have some U.S. investors (not necessarily covered ${ }^{21}$ ) and situations where the foreign entities involved actively traded in U.S. markets. ${ }^{22}$ This emphasis on listings and markets, however, is highly problematic. The process of globalized trading shows that multiple competing trading markets for securities are gradually becoming the norm; if so, the notion of a mere listing as a choice of a trading market by an issuer that operates as some sort of a representation or assumption of responsibility to the investing public of that jurisdiction becomes anachronistic. Indeed, it would not be surprising to see the gradual

17. See SEC v Texas Gulf Sulphur Co., 401 F2d 833, 860 (2d Cir 1968) (en banc) (fraud on the market rationale).

18. See, for example, Affliated Ute Citizens v United States, 406 US 128, $152-54$ (1972).

19. Although Rule 10b-5 has been interpreted to apply only to intentional misconduct, Emst $\mathcal{E}^{\circ}$ Ernst $v$ Hochfelder, 425 US 185 (1976), that notion is broad enough to encompass severe recklessness, for example, Broad y Rockwell Intl Corp., 642 F2d 929, 961-62 (5th Cir 1981), as well as utilitarian lies. On the issue of open-endedness, see James D. Cox, Ernst \& Ernst v. Hochfelder: A Critique and an Evaluation of Its Impact upon the Scheme of the Federal Securities Laws, 28 Hastings L J 569 (1977).

20. This hypothetical, of course, is based on Basic Inc. v Levinson, 485 US 224 (1988). However one feels about the result, it does seem that a variety of debatable policy choices are subsumed in the Court's conclusion. See, for discussion, Jonathan R. Macey \& Geoffrey P. Miller, Good Finance, Bad Economics: An Analysis of the Fraud on the Market Theory, 42 Stan L Rev 1059 (1990).

21. See dicta in Bersch $v$ Drexel Firestone Inc., 519 F2d 974, 992 (2d Cir 1975).

22. A somewhat extreme example of the latter is Des Brisay v Goldfield Corp., 549 F2d 133 (9th Cir 1977), where the court found effects-based jurisdiction in a class action brought by Canadian investors because the defrauding company was traded in the United States, and the exposure of the fraud caused a collapse of its market. 
deemphasis of the notion of listing, and its replacement instead with simple inclusion in one or more trading markets (with or without the consent of the issuer). It plainly overreaches to suggest that a country should engage in post-investment fiduciary standard-setting simply because that country is one of the locales for trading in the underlying security.

2. The Conduct Test. The alternative approach to exercising subject matter jurisdiction in fraud cases is the "conduct" test: a sufficient measure of conduct in the United States will lead to the application of Rule 10b-5, even if the harmful effects are completely foreign. In contrast to the effects test, there is a lingering disagreement among U.S. courts about the proper way even to frame the conduct test: approaches run from the quite liberal to the fairly restrictive. ${ }^{23}$ This no doubt reflects a failure to articulate with any precision why subject matter jurisdiction should be exercised at all when the persons harmed reside abroad and have the right to seek redress in their own courts, given the costs associated with opening the doors of the U.S. courtrooms to them.

Two reasons to exercise subject matter jurisdiction conservatively seem plausible. One is that the United States has a reputational interest in not being used as a base of operations (what some courts have referred to as a "Barbary Coast"24) for securities fraud, an interest significant not only for internal purposes but also as an important "chip" in negotiating with other countries toward a more cooperative system of international enforcement. ${ }^{25}$ The other is efficiency-based: under many circumstances, the country where the conduct occurs is in a far better position to investigate and enforce the law more effectively or at lower cost than those countries where the harm is felt, especially when the harm is relatively diffused. Building a cooperative system of international enforcement suggests that countries should be willing to exercise such jurisdiction when they are the most efficient enforcers. But to date, outcomes in the conduct cases (if not always the rhetoric) seem influenced less by this functional analysis than simplistic, ad hoc judgments of whether the conduct was "substantial enough."

Once more, the clumsy fit between this conceptual approach and the nature of the global securities marketplace is readily apparent. Given the advances in communications technology, physical presence is largely a random (and not terribly relevant) event; gradually, more economic activity involves multi-jurisdictional conduct-or more precisely, conduct that is difficult to place in any meaningful sense at all. Again, and especially given

23. See James D. Cox, Robert W. Hillman \& Donald C. Langevoort, Securties Regulation: Cases and Materials 1342-63 (Little Brown, 1991) ("Cox Casebook"). A liberal approach is suggested by SEC $v$ Kasser, 548 F2d 109 (3d Cir 1977), to the effect that activities are sufficient in the United States if they were an important factor in bringing about the harm. On the other hand, a much more restrictive approach is articulated in Zoelsch v Arthur Andersen $\mathcal{E}^{3}$ Co., 824 F2d 27 (DC Cir 1987), taking the view that the essential elements of the fraudulent misconduct must have occurred here.

24. See, for example, SEC v Kasser, 548 F2d at 116.

25. Id. This notion includes the idea that some forms of domestic conduct may be sufficiently repugnant that their proscription is desirable for that reason alone. 
the functions supposedly served by the conduct approach, simply looking for sufficient local conduct (or even trying to make artificial judgments about where the "essential" elements of the fraud occurred) does not seem terribly sophisticated, and raises the same concerns about conflict and jurisdictional overreaching noted with respect to an overbroad notion of effects-based jurisdiction. This critique is especially true given that most cases raising extraterritoriality questions are private actions brought with no reason to care about sound jurisdictional scope.

\section{The Third Restatement}

Recognizing the potential for conflict and overbreadth in the application of U.S. law abroad is not a new insight by any means: concern about the extraterritorial application of the U.S. antitrust laws, in particular, has been well documented. Responding to this potential, the American Law Institute approved its Restatement (Third) of the Foreign Relations Law of the United States in 1986 with a direction, in the abstract at least, that after finding either the effects or conduct test satisfied, courts determine in addition whether the exercise of jurisdiction would be "reasonable" in assessing jurisdiction to prescribe. ${ }^{26}$ In determining reasonableness, a variety of factors are considered, many of which go to the possibility of conflict among jurisdictions, or the notion that another jurisdiction might have a superior claim to set the prevailing law. In addition, inquiry is directed to "the existence of justified expectations that might be protected or hurt by the regulation." 27 By all accounts, this is an attempt to move the law regarding extraterritoriality more toward a conflicts-of-law-style treatment. ${ }^{28}$ When applied, these standards are often grouped under the rubric of comity.

The Third Restatement is a significant step, since the prior version was so influential, and the new one's emphasis on comity urges caution against precisely the sort of overbreadth exhibited in the approaches that have thus far been utilized in the case of securities. To date, however, its balancing approach has not had a great influence on the outcomes in fraud cases. One opinion, Judge Bork's for the D.C. Circuit in Zoelsch v. Arthur Andersen E Co., ${ }^{29}$

26. See Restatement (Third) of the Foreign Relations Law of the United States, $\S 401$ comment C ( Jurisdiction depends "on a concept of reasonableness based on a number of factors."). The Restatement has a specific provision, $\$ 416$, dealing with securities cases. Certain sorts of conduct (such as trades carried out on an organized exchange in the United States) trigger the jurisdiction to regulate without regard to the reasonableness factors (subsection 1); for other types of conduct, a finding of reasonableness is required (subsection 2). For a variety of reasons, the list in subsection 1 itself may be overinclusive. For an overview of the history and meaning of this reasonableness inquiry, see Harold G. Maier, Resolving Extraterritorial Conficts, or "There and Back Again," 25 Va J Intl L 7 (1984).

27. Restatement (Third) of the Foreign Relations Law of the United States, § 403(2)(d).

28. The relationship between conflicts reasoning and extraterritoriality decisions has been noted by a number of scholars. See Lea Brilmayer, The Extraterritorial Application of U.S. Law: A Methodological and Constitutional Appraisal, 50 L \& Contemp Probs 10 (Summer 1987); Harold G. Maier, Extraterritorial Jurisdiction at a Crossroads: An Intersection Between Public and Private International Law, 76 Am J Intl L 280 (1982).

29. 824 F2d 27, 31 (DC Cir 1987). 
explicitly rejects the balancing idea in the securities context because of its inherent fuzziness and unpredictability. Others cite the Restatement, but in the end either do not conduct a serious reasonableness inquiry or else find the factors conflicting or unhelpful. ${ }^{30}$ To some extent, this is a product of the simplistic assumption that since fraud is bad, its proscription is inevitably reasonable. $^{31}$ Whatever the explanation, both the pre- and post-Restatement securities fraud cases retain a substantial methodological bias toward finding subject matter jurisdiction, ${ }^{32}$ a bias that will increasingly be accommodated in the global securities marketplace unless limiting factors are more consciously introduced into the decisionmaking process.

III

\section{Why Is Restraint ApPropriate?}

If the courts thus far have not shown much systematic willingness to restrain the application of Rule $10 \mathrm{~b}-5$, why should things change? After all, breadth is not necessarily an evil when what is achieved is a good result. Although nearly all nations prohibit securities fraud, they generally employ fewer resources (often dramatically so) in its detection and remedy. Deference to another country's corporate/securities law domain will often carry with it the risk that sanction will be less than we would like, or that there will be no sanction at all.

There are nonetheless three reasons, becoming all the more vivid as the pace of internationalization increases, favoring restraint. The first is cost, a factor that has sometimes been recognized by the courts. ${ }^{33}$ As noted earlier, the process of internationalization brings with it far greater opportunity to observe both effects and conduct in multiple countries (especially the United States) with respect to any given transaction or occurrence. Thus, we can expect the number of plaintiffs raising extraterritoriality issues to grow dramatically, and if heard by our courts, the incremental claim on our judicial resources will increase proportionately, forcing us to consider seriously whether the anticipated benefits from the exercise of jurisdiction are worth the costs.

30. See, for example, AVC Nederland B.V. v Atrium Investment Partnership, 740 F2d 148, 154-55 (2d Cir 1984); CL-Alexanders Laing E Cruickshank v Goldfeld, 709 F Supp 472, 479-80 (SD NY 1989). The Restatement has been criticized for, among other things, its lack of direction as to how to balance the various factors and thus its lack of rigor. See, for example, Karl M. Meessen, Conficts of Jurisdiction Under the New Restatement, 50 L \& Contemp Probs 47 (Summer 1987).

31. This assumption is found in some of the literature as well. See Andreas F. Lowenfeld, Jurisdiction to Prescribe: Some Contributions From an International Lawyer, 4 BU Intl L J 91,95 (1986) (suggesting that conflicts among jurisdictions are unlikely where fraud is involved).

32. This is not to say that the overwhelming number of cases will come out in favor of jurisdiction. Indeed, there are many examples of decisions to the contrary. See, for example, Zoelsch, 824 F2d at 34-36 (DC Cir 1987); Fidenas $A G v$ Compagnie Internationale, 606 F2d 5 (2d Cir 1979). Rather, by focusing almost exclusively on whether the effects were substantial enough or the conduct sufficient enough, the courts have assumed a myopia that will increasingly make it possible to justify an assertion of jurisdiction without proper account of competing factors.

33. See, for example, Bersch, 519 F2d at 985. 
A second reason is competitive. To the extent that Rule 10b-5 is perceived as a significant risk factor, it is possible to style transactions by strictly excluding U.S. investors, refusing to use even the foreign offices of U.S.-based securities institutions (for example, the lawyers, accountants, and investment bankers whose role has been noted as a basis for finding jurisdiction in a number of cases $^{34}$ ), and/or routing trades to non-U.S. trading markets. ${ }^{35}$ Schoenbaum itself provides ample reason, for example, why the management of a foreign issuer might shy away from a U.S. listing. While a chill that causes blatant wrongdoers to locate elsewhere is hardly bothersome, there is little doubt that fear of liability is felt by a far broader and more benign class of actors. Here, the process of exclusion, as the SEC has acknowledged in other contexts, ${ }^{36}$ is counterproductive to U.S. economic interests.

The third is that a policy of self-restraint is a necessary precondition to the establishment of the effective, cooperative scheme of international securities regulation we profess to seek. Too aggressive a U.S. regulatory posture, particularly when some other country has a superior claim to domain, sends two unfortunate messages. One is that other countries can free-ride, depending on the United States rather than devoting appropriate resources themselves to their capital market involvement. The resulting underfunding could retard the development of a potent international regulatory system. The other message is that other countries are deemed inferior regulators, hardly the show of respect that invites cooperative participation in multinational enforcement or the negotiations necessary to pursue the twin regulatory strategies for dealing with globalization: harmonization and reciprocity.

\section{IV}

\section{"Scope" Revisited: Toward a More Unified Approach}

The question, therefore, becomes how to introduce greater restraint regarding the extraterritorial application of U.S. law into the judicial decisionmaking process. Simply posing the question in this way suggests some direction, since there is a familiar ring to it. Over the last two decades, the courts have been engaged in the process of limiting the substantive scope of Rule 10b-5 based on concerns about domestic overbreadth and the need for harmonization with alternative regulatory schemes. In essence, these too are

34. See, for example, Grunenthal GmbH v Hotz, 712 F2d 421, 425 (9th Cir 1983). Often, ironically, courts justify the assertion of jurisdiction on the desire to protect such firms from being co-opted into fraudulent schemes by foreigners.

35. The use of U.S. markets as part of the unlawful activity has been considered a factor under both the effects and conduct tests. See, for example, Psimenos v E.F. Hutton E Co., 722 F2d 1041 , 1045-47 (2d Cir 1983) (conduct); Tamariv Bache E Co. (Lebanon) S.A.L., 730 F2d 1103, 1108 (7th Cir 1984) (both).

36. Securities Act Rel No 6897 (June 5, 1991), proposing Rules that would deregulate in the tender offer area so as to lessen the likelihood that foreign bidders would exclude U.S. investors from takeover bids because of concern about the Williams Act. See International Tender and Exchange Offers (Securities Act Rel No 6857), 56 Fed Reg 27,582 (1991) (proposed rules, forms, and order impacting 17 CFR $\S \$ 200,230,239,240$, and 260 ). 
subject matter jurisdiction decisions, and so fall in the same genre as the extraterritoriality cases. Perhaps we can extract from these a common body of interests and factors to be considered by the courts-standard questions to be asked-in deciding to which conduct the law applies, and to which it does not.

My sense is that we can introduce greater restraint. Coincidentally or not, two of the limiting factors identified by the Third Restatement-comparative inquiry into appropriate legal domain and assessment of the justifiable expectations of the parties-have for some time now been invoked more or less explicitly to limit the substantive scope of the antifraud provisions. ${ }^{37}$ If attention to these is part and parcel of any sensitive attempt to determine subject matter jurisdiction in securities fraud cases, then there is both a logic and a substantive appeal to extending that attention to the multi-national fraud setting, quite apart from the direction given by an exogenous legal source (which in fact addresses a very different question) like the Restatement.

Before we turn to the case law, these two limiting factors should be understood clearly. In inquiring about appropriate legal domain, a court is assessing the extent to which the fact pattern before it "belongs" in a particular legal regime. That assessment is highly contextual, going to whether the sorts of behaviors involved are best addressed by deference to a single system of interrelated conduct rules and enforcement strategies, and if so, which one. ${ }^{38}$ The answer, in turn, often comes by looking at a second factor, the reasonable expectations of the parties. The behavior of economic actors is guided by the legal systems they reasonably perceive to apply; $;^{39}$ a counterintuitive choice of regime will not influence most actors, and may in certain types of cases seem unfair when applied after the fact. Moreover, adherence to the expectations of the parties facilitates ex ante risk allocation, a reason for its now-standard usage as an intellectual building block in nearly all contract-based legal doctrines.

There are at least three threshold areas in the prevailing securities fraud jurisprudence where these factors have already assumed significance, from which courts in extraterritoriality cases could fruitfully draw to support a reasonableness inquiry.

37. See notes 49-52 and accompanying text.

38. As a policy matter, this value seems self-evident. Among other things, placing a problem in the right legal domain best assures that it will be treated in a manner similar to like problems, with due attention to the subtleties of the particular context derived from the precedent in the area. Moreover, the decision so generated becomes part of that precedent, and so can guide future decisionmaking.

39. There is of course an element of circularity to the concept of reasonable expectations about prevailing legal principles: the choice to afford protection by the courts makes it reasonable to expect protection. As used in common law settings, however, the idea employed here is that reasonable actors (for example, typical investors) are not legal experts, but do have some intuitive sense of the nature and source of legal protections. Reasonable expectations about legal protection are those that someone operating largely on common sense would anticipate. 


\section{A. Defining Fraud}

One of the most vexing questions in the jurisprudence of Rule 10b-5 arises when one attempts to give meaning to the term "fraud." 40 The core concept is easy: A person who is tricked by a lie into parting with his or her money or property has plainly been defrauded. This concept is transactional, captured at common law by the phrase "fraud in the inducement," and many securities frauds fit readily into this category.

But there are many other cases that do not. Insider trading cases provide many examples, such as the "abstain or disclose theory," characterized by the absence of any affirmative communication or expectation of disclosure, and the misappropriation theory, under which the defrauded person makes no securities transaction at all. The broker-dealer fraud cases involving discretionary accounts (for example, churning) also do not fit the traditional fraud definition.

The paradigmatic setting, however, is the sort of instance of corporate mismanagement considered in Schoenbaum. In such cases, one or more members of senior management engage in some sort of self-dealing transaction involving securities (usually, either the issuance of new stock to themselves at an unduly low price, or the sale of their stock to the corporation or an affiliate at an inflated price). The allegation is not that the shareholders were defrauded as individual buyers or sellers of securities, but rather that the corporation itself was defrauded in the course of this misbehavior.

Precisely how the courts react to this type of case is a story that is still evolving, but the story teaches some interesting lessons. Schoenbaum held that this sort of case states a claim under Rule 10b-5.11 In essence, its logic was that since the knowledge of the managers is not, because of the corrupt nature of their behavior, attributed to the corporation, it is fair to say that the entity itself was deceived. This approach, however, operated to turn virtually any breach of fiduciary duty involving a securities transaction into a fraud.

In a subsequent case, ${ }^{42}$ the Second Circuit took the next logical step, suggesting that all a plaintiff need do in a case of corporate mismanagement is plead a breach of fiduciary duty-in essence, a recognition that fraud under Rule 10b-5 encompasses the full range of that which at common law is referred to as "constructive fraud." The Second Circuit's action provoked a reversal by the Supreme Court in Santa Fe, holding that actual deception must be alleged. The Supreme Court justified the reversal by reference to a mixture of plain language and legislative history, but also said-in the most controversial portion of the opinion-that it was guided by a concern that corporate mismanagement per se is meant to be addressed in a different legal

40. See generally Donald C. Langevoort, Fraud and Deception by Securities Professionals, 61 Tex L Rev 1247 (1983).

41. Schoenbaum, 405 F2d at 208-09 (this holding was explicitly left undisturbed by the court en banc, 405 F2d 215 at 217 ).

42. Green v Santa Fe Industries, Inc., 533 F2d 1283, 1289-91 (2d Cir 1976). 
domain-state corporation law-and that principles of federalism require a more limited scope to the meaning of fraud. ${ }^{43}$

In the mismanagement cases themselves, Santa $\mathrm{Fe}$ has not accomplished all that much. Subsequent decisions by the lower courts, by and large, returned to the Schoinbaum logic, requiring only an express allegation that some material fact relating to the misbehavior have been misstated or withheld from the company's shareholders. ${ }^{44}$ In practical terms, the courts are saying that had there been full disclosure to the only disinterested parties available, the shareholders, they could have protected themselves through a state court injunctive action or some other measure. Thus, the courts have not imposed much of a limitation at all on mismanagement actions, since virtually all misconduct has some element of secrecy or cover-up. But even here, there are hints that some courts are growing uncomfortable with the "end run" character of this analysis, given the federalism concerns of Santa $\mathrm{Fe}^{45}$ : the Second Circuit itself, in its most recent decision, has pruned Schoenbaum substantially by requiring that the plaintiff allege a clear case of corruption (one where there is no question of conflict with state law) so as to avoid too great an intrusion on the states' domain in fashioning rules of conduct, ${ }^{46}$ and the Supreme Court has hinted that a highly restrictive standard of causation should be applied in cases like these. ${ }^{47}$

The more interesting turn has been the impact of Santa $\mathrm{Fe}$ in other types of "relational fraud" cases. In a number of instances, courts have dismissed Rule 10b-5 actions, citing Santa Fe, where the allegation of misconduct seemed to fall more into some other legal domain (such as contract law or the law of trusts). ${ }^{48}$ While these decisions do not always say so, in essence they are not so much holdings on the meaning of deception-since the same allegation is present as in the mismanagement cases: that had the plaintiff known of the fiduciary misconduct, he or she could have taken protective action-as holdings that the alleged deception should not be deemed "in connection with the purchase or sale of a security." Thus, we must continue our story by moving to that rubric.

\section{B. The "In Connection With" Requirement}

Logically, a claim that an instance of fraud belongs in some other legal domain states an "in connection with" conclusion: that the fraud is not sufficiently connected with the world of investment and securities trading (the

43. Santa Fe Industries, Inc. v. Green, 430 US 462, $478-79$ (1977).

44. See, for example, Goldberg $v$ Meridor, 567 F2d 209, 217-18 (2d Cir 1977).

45. See Harris Trust and Savings Bank v Ellis, 810 F2d 700, 704 (7th Cir 1987) ("More recent cases .. . reflect dissatisfaction with these holdings, because they use the securities laws to redress substantive violations of state law.").

46. Field $v$ Trump, 850 F2d 938, 948-49 (2d Cir 1988).

47. Virginia Bankshares, Inc. $v$ Sandberg, 111 S Ct 2749, 2765-66 (1991) (suggesting, at least with respect to cases brought under the proxy rules, that fraud is not actionable under this sort of theory unless the state law remedy is lost entirely, construing Securities Exchange Act of $1934 \S 14$ (a)).

48. A vivid example is Pross $v$ Katz, 784 F2d 455 (2d Cir 1986); see also O'Brien $v$ Continental Illinois Natl Bank E Trust, 593 F2d 54 (7th Cir 1979). 
world Congress was addressing in 1934) to justify the exercise of subject matter jurisdiction. While the bulk of "in connection with" cases exhibit little coherence (the majority, in fact, treating it as something of a causation question), ${ }^{49}$ there is a good bit of doctrine here that asks questions that are very much in the Santa Fe vein.

One illustration is the set of close corporation cases, like Ketchum $v$. Green, ${ }^{50}$ where an employee is somehow tricked into quitting his or her job and giving up equity interest in the firm. Where the essential nature of the dispute has to do with employment relations or corporate governance, the stock buy-back aspect is deemed incidental and the matter is treated under some alternative legal regime. The opposite conclusion is reached, on the other hand, when the trick was designed specifically to obtain the victim's stock. ${ }^{51}$ There is a host of other cases where, explicitly or implicitly, the court seems to be filtering out cases for treatment under another legal domain. For instance, Chemical Bank v. Arthur Andersen $\mathcal{E}^{2}$ Co. ${ }^{52}$ held that (notwithstanding the presence of "but for" causation) fraud in the course of securing a commercial loan that involved the pledge of certain stock as collateral was not "in connection with" the purchase or sale of a security.

By focusing on domain questions, these cases-as well as Santa $F e$ and its progeny-are making scope determinations by reference to legal "fit." The courts seem to be asking if a given case is best dealt with by reference to Congress' securities law objectives (encouraging investment-related activity free of the fear of fraud or deceit), which have driven the creation of the prevailing doctrinal structure, or if some other legal structure is better suited to address the matter. To some extent, this is a question of legislative intent; alternatively, it could also be viewed as a question of the parties' reasonable expectations as to the applicable field of law.

\section{Defining "Security"}

Although it is not a Rule $10 \mathrm{~b}-5$ issue as such, the first threshold question in any securities fraud case is whether there is a "security" involved at all. Hence, it is appropriate to look to this question as another important "scope" issue for purposes of determining subject matter jurisdiction.

As with the foregoing scope contexts, it would be foolish to suggest that there is a coherent doctrinal structure from which to draw in defining "security." The continuing difficulties in deciding what is an "investment contract" aptly demonstrate the contrary. But a close inspection of the case

49. See, for example, Cox Casebook at 724-28 (cited in note 23); C. Edward Fletcher III, The "In Connection With" Requirement of Rule 10b-5, 16 Pepperdine L Rev 913 (1989).

50. 557 F2d 1022 (3d Cir 1977). Ketchum was actually a more complicated variant of this problem, since the employees voted in directors who immediately fired the employees.

51. Brown v Ivie, 661 F2d 62 (5th Cir 1981).

52. 726 F2d 930 (2d Cir 1983). The court hinted at a reasonable expectations approach as well, observing that no one could reasonably have known that the pledge element would affect the legal status of the parties. Id at 944 . 
law shows an increasing willingness to invoke the same sort of domain and reasonable expectation approaches described above.

The use of appropriate domain is the easiest to find. In a series of cases beginning with International Brotherhood of Teamsters $v$. Daniel,,$^{53}$ the Supreme Court has held that an instrument may not be a "security" if there exists an alternative regulatory scheme that provides a better fit, even if the instrument technically also falls under one or more of the "security" definitions.

The most intriguing use of the scope approach is found in the Supreme Court's most recent definition case, Reves $v$. Ernst E Young. ${ }^{54}$ Although the Court limited itself to the narrow question of when a promissory note is or is not to be treated as a security (and then proceeded with an opinion that is full of internal contradictions ${ }^{55}$ ), the Court formulated a test that may be applied to the definition of "security" in general. The Court held that, in assessing whether a novel debtor-creditor relationship should be treated as within the scope of the federal securities laws, attention should be paid to: (1) the motivations that prompt buyer and seller to deal with each other; (2) the method by which the instrument in question is distributed (such as through traditional securities channels or markets); (3) the reasonable expectations of the investing public; and (4) whether an alternative regulatory scheme addresses the issue (or some other risk-reducing device is present) ${ }^{56}$ In this one setting, at least, there could hardly be a stronger endorsement of the idea that applicability of the securities laws should be determined by reference to the legal domain to which reasonable actors would assign the transactionprecisely the approach advocated here. And notwithstanding the Court's narrow statement of the question, there is no reason whatsoever why the same approach should not or will not be invoked in all the cases involving the definition of "security," particularly the meaning of "investment contract." If case law in this area takes this turn, it will create an appealing unity with the other scope questions.

\section{SCOPE AND EXTRATERRITORIALITY}

We have seen, now, that it is hardly uncommon in securities fraud cases to ask whether peoples' reasonable expectations would lead them to believe that the protection of the prevailing statutory scheme is likely, or whether the essential elements of the alleged misconduct fit better under some alternative regulatory scheme. To ask in the international setting-to consider whether reasonable actors would reasonably expect the protection of U.S. law, or

53. 439 US 551 (1979); see also Marine Bank $v$ Weaver, 455 US 551 (1982).

54. 494 US 56 (1990).

55. Explored in an amusing fashion in James D. Gordon III, Interplanetary Intelligence About Promissory Notes as Securities, 69 Tex L Rev 383 (1990).

56. For an application of the public expectations aspect of this test finding the fraud to lie in another law's domain, see Premier Microwave Corp. v Comtech Telecomm. Corp, [1990-91 Transfer Binder] Fed Secur L Rptr (CCH) ๆ 95,789 (SD NY 1991); Varnberg v Minnick, [1990-91 Transfer Binder] Fed Secur L Rptr (CCH) ๆ 95,831 (SD NY 1991). 
whether some foreign regulatory scheme offers a better fit for the conduct in question-would effect a sensible doctrinal continuity.

Without more, however, phrases like "appropriate domain" and "reasonable expectation" are fairly empty ones, promising little in the way of sensible determinacy. In this section, therefore, I will try to give some meaning to these phrases as they might apply to the multinational setting. The best way to proceed is by defining what the generally understood scope of the antifraud provisions is, rather than what it is not. In my view, one can glean from the case law (and to a lesser extent legislative sources) that these provisions have as their operative purpose the encouragement of desirable investment-related behavior in the United States by diminishing the fear of fraud and manipulation that might otherwise chill such activity. That is to say, Congress was seeking to proscribe fraud, deceit, or manipulation that might compromise the integrity of the investment decisions made by investors who are either based in the United States or considering investment in U.S.-based issuers, or compromise the integrity of the market mechanisms that facilitate investment activity. (By investment-related behavior, I mean the full range of activity surrounding the process of buying and selling securities that is addressed in the case law dealing with the "in connection with" requirement under Rule 10b-5.) I suspect that most economic actors have an intuitive sense that they can expect either protection or sanction to the extent that their activity relates to one of these goals. Let us now see how much doctrinal revisionism we can accomplish by reference to this statement of "appropriate domain."

\section{A. The Easier Setting: Conduct Revisited}

The obvious candidate for pruning is the conduct test, especially since it is the primary culprit in creating the sorts of competitive disadvantages noted earlier. ${ }^{57}$ After all (and as Judge Bork observed in Zoelsch ${ }^{58}$ ), there is relatively little in our understanding of the appropriate domain of the antifraud provisions to suggest that it would be beneficial to reach fraud with a wholly foreign impact. As demonstrated above, the U.S. interest here is a secondlevel, reputational one. We wish to communicate that our markets and investments are credible ("core values," as discussed above), and do not wish to harbor activity that might undermine the tone we wish to set. In addition, there is an important "good neighbor" aspect to this test, given the investigatory and remedial efficiencies that can sometimes come from asserting this sort of jurisdiction. ${ }^{59}$ To this extent, the domain of U.S. law should be reasonably clear: there is sufficient conduct to justify jurisdiction if and only if the investment-related facilities of U.S. commerce have been appropriated in the perpetration of a fraud in such a way that the U.S.

57. See notes $34-36$ and accompanying text.

58. Zoelsch v Arthur Andersen E Co, 824 F2d 27 (DC Cir 1987).

59. This should not be overstated, since at least in terms of public enforcement, the SEC is now empowered to assist foreign governments in the U.S.-based phases of securities law investigations. See 15 USC \& 78u(a)(2) (1989). 
reputation is somehow compromised. In close cases, it is appropriate to ask whether application of domestic law would materially aid the efficient resolution of the proceeding. Beyond this, foreign citizens have little reason to expect the protection of U.S. law, as opposed to the law of the site of the harmful effects.

This test alone sets some useful limits on the exercise of subject matter jurisdiction. Two cases from the 1980 s are illustrative. In $A V C$ Nederland B.V. $v$. Atrium Investment Partnership, ${ }^{60}$ a Dutch corporation sued Dutch promoters of a nominally U.S. investment partnership, claiming fraud in the offering materials (which were prepared abroad). The Second Circuit decided that Rule 10b-5 applied largely because the subject of the investment (certain real estate) was located in the United States, and because some of the alleged misrepresentations occurred during trips to the United States to inspect the properties. This result seems wrong in light of a refined understanding of the scope of Rule 10b-5. The contacts in the United States were not such that the United States could be seen to have somehow harbored the fraud (the home base for the fraudulent scheme was plainly the Netherlands). Further, there is little reason to expect that the application of U.S. law would promise a more efficient resolution of the case than setting the matter in the Netherlands, where the fraud was formulated and the harm took place. ${ }^{61}$

Similarly, Psimenos v. E.F. Hutton $\mathcal{E}^{2}$ Co., ${ }^{62}$ applied U.S. commodities law to protect a Greek citizen whose account was churned by brokers in the Athens office of E.F. Hutton. The court justified this conclusion in part by reference to the existence in New York of some supervisory responsibility over the Athens office (though there were no allegations of knowledge or acquiescence). More importantly, the allegedly excessive trades were executed in Chicago, on U.S. commodities exchanges. These justifications seem weak, however. The supervisory point did not represent a significant aspect of the case, and there was no reason to believe that the informational or transactional integrity of the commodities markets in the United States was compromised by this small level of improper trading. Furthermore, the effect of this kind of decision may be exceedingly unfortunate from a competitive standpoint, for by holding the Athens office of Hutton to a different and potentially more burdensome standard of conduct than its local rivals, ${ }^{63}$ the

60. 740 F2d 148 (2d Cir 1984).

61. Another troublesome case for similar reasons is Grunenthal GmbH v Hotz, 712 F2d 421 (9th Cir 1983), where the court reversed the lower court's refusal to assert jurisdiction in a situation where the utterance of the fraudulent statements in the United States was merely a repetition of an earlier misrepresentation, and the parties were in the United States largely as a matter of convenience. The appellate court felt that abstaining from exercising jurisdiction could operate to encourage people to come to the United States for convenience, apparently not recognizing that the more serious likelihood would be the opposite: those perceiving Rule $10 \mathrm{~b}-5$ as an unnecessary risk would carefully avoid anything to do with U.S. investment-related facilities and institutions.

62. 722 F2d 1041 (2d Cir 1983); see also Tamari v Bache E Co. (Lebanon) S.A.L., 730 F2d 1103 (7th Cir 1984).

63. On this issue in the context of extraterritorial application generally, see Jonathan Turley, "When In Rome": Multinational Misconduct and the Presumption Against Extraterritoriality, 84 Nw U L Rev 598 (1990). 
court creates a substantial disincentive for the use of U.S. markets as trading locations when (as is increasingly the case) there is a choice.

\section{B. The Harder Setting: Effects Revisited}

Much more problematic is the effects test. Under the scope of the antifraud provisions we have defined, there is still the core value in protecting the integrity of both domestic investor decisions and market mechanisms. The presence of this value necessarily indicates that the effects test will be broad in scope. Misstatements or actionable omissions that are calculated to influence U.S.-based investors ${ }^{64}$ (a test many people understand in terms of foreseeable influence) are proscribed wherever they occur, for example, subject only to the statutory requirement that the facilities of interstate commerce be used. ${ }^{65}$ A person who knowingly places false information in a database that is accessible to U.S. investors likely commits a violation of Rule 10b-5. And this effectively invites the Americanization of the antifraud law relating to all significant forms of issuer disclosure, for the reasons noted earlier. ${ }^{66}$

Our approach does introduce some limitation to the prevailing doctrine. Take Schoenbaum, for example. In essence, the theory in that case is that $a$ Canadian company was defrauded by activities in Canada by Canadian defendants. The U.S.-based investors' right to sue was solely derivative in nature (that is, on behalf of that company). As understood today, the only thing the shareholders themselves were deprived of was the opportunity to go to court in Canada to seek equitable relief in a derivative action. The tainted purchase/sale "decision" itself was wholly foreign.

64. For example, SEC v Texas Gulf Sulphur Co., 401 F2d 833, 860-62 (2d Cir 1968).

65. There is obvious potential in this statutory requirement for pruning the extraterritorial scope of the law; strictly construed, it could put some amount of foreign conduct outside the reach of Rule 10b-5-even though such foreign conduct might foreseeably affect U.S. interests. See, for example, Plessy Co. PLC v General Electric Co. PLC, 628 F Supp 477 (D Del 1986). While there is relatively little law on the meaning of direct or indirect use of the facilities of interstate commerce in the global markets, the courts thus far in domestic cases have not been strict constructionists. See Louis Loss \& Joel Seligman, Securities Regulation 425-27 (3rd ed Little Brown, 1989). And in the roughly analogous setting of the mail and wire fraud statutes, courts have been willing to base jurisdiction on the foreseeable use of the facilities (including use solely by the victim). See, for example, $U . S$. v Conte, 349 F2d 304, 306 (6th Cir 1965). Putting aside the interpretive question per se, emphasis on the "facilities" question would be a blunderbuss way of restraining the law, since it would insulate conduct without regard to the policies underlying the law. Grossly manipulative frauds could be insulated from liability. A better posture, then, is to construe the jurisdictional means test broadly (for example, as encompassing the foreseeable use of the facilities) and control jurisdiction through the more sensitive subject matter test.

66. It may be tempting to limit the scope of U.S. law by insisting that the tainted purchase or sale must have occurred in the United States. But this limitation invites some core types of fraud, especially as technology enhances the ability to engage in foreign transactions. It should be noted that if U.S. investors consciously waive the protection of U.S. law by setting up a foreign investment entity for the purpose of making investments in securities from which U.S. investors are otherwise excluded, there is no reason to apply Rule $10 \mathrm{~b}-5$ when they discover the fraud. See, for example, MCG Inc. $v$ Great Western Energy Corp., 896 F2d 170, 175 (5th Cir 1990). This is true even if the tainted investment decision occurred here. 
The court in Schoenbaum stressed the fact that the company's shares were listed for trading on the U.S. Stock Exchange. To the extent that company officials were distorting or manipulating the market price, the sort of misconduct involved might well be actionable, since, as we have seen, protecting the integrity of the U.S. markets (as well as domestic investment decisions) is a core value. But the Schoenbaum case itself does not rest on this sort of assertion; it is a derivative, not a direct, cause of action. It is hard to imagine that an U.S. investor who buys the shares of a foreign company reasonably expects the subsequent protection of the U.S. securities laws simply because the company was led to make a poor investment decision abroad by the malfeasance of its managers. Intuitively, that is another law's domain. ${ }^{67}$

With a better understanding of appropriate domain and reasonable expectation, then, some pruning can be done. But it is really relatively little. In Schoenbaum, for instance, we can say that the particular cause of action for existing company shareholders should not lie. But suppose that under the same set of facts, persons who bought the Canadian company's stock on the U.S. Stock Exchange before the misconduct was fully disclosed (or the SEC) brought suit. Assuming the materiality of the misconduct, that action would be a matter of domestic concern, since the market price would be distorted. U.S. law would still reach the underlying conduct; 68 only standing to sue would be restrained, and not to any great extent. This brings us back to the conceptual overbreadth of the effects test, given the integrated, systemic nature of the international capital marketplace. There is no way around it so long as the articulated goals underlying Rule $10 \mathrm{~b}-5$ are pursued.

Should the scope of jurisdiction be narrowed? If we can abandon the idea that our conception of investor protection is an end in and of itselfsomething that Congress or the SEC could do far more easily than the courts, given the long history of contrary thinking ${ }^{69}$-we could consider limiting

67. In an important decision of recent vintage, the First Circuit applied the doctrine of forum non conveniens to force the dismissal of an action under Rule 10b-5. The claim was brought in an U.S. court; however, the fraud was almost exclusively foreign and the shares were bought abroad by U.S. investors. The court even assumed the presence of subject matter jurisdiction in its decision to dismiss. Howe v Goldcorp Investments Ltd., 946 F2d 944 (1st Cir 1991). The court noted that neither the plaintiff "nor the SEC has provided us with any reason to believe [that the federal securities] laws seek so strongly to protect Americans who bought their shares abroad from misrepresentations ... primarily taking place abroad that a court may not require an U.S. shareholder to bring his case abroad in a nation that offers its shareholders roughly equivalent legal protections." Id at 953 (emphasis in original). While this ruling goes in the right direction, the power of the procedural doctrine employed is limited to the extent that it requires "roughly equivalent protection" in the foreign court. Effectively, that means that actions are most likely to be dismissed in cases of core fraud, and least likely when the foreign jurisdiction has adopted a substantially different (that is, deregulatory) approach. And it is the latter setting where the potential for implicit conflicts is most severe.

68. The breadth of U.S. law in this setting is great, since it is not very difficult to characterize improper managerial behavior as "material" for purposes of a fraud claim. See, for example, Cox Casebook at $97-117$ (cited in note 23 ).

69 . Interestingly, $\S 10(\mathrm{~b})$ as originally enacted, probably did not have investor protection per se as an objective but rather was designed to operate as a broad-based mechanism by which the SEC could assure that the markets were not distorted by manipulative or speculative activity. See Steve Thel, The Original Conception of Section 1O(b) of the Securities Exchange Act, 42 Stan L Rev 385 (1990). 
effects-type subject matter jurisdiction under Rule $10 \mathrm{~b}-5$ solely to the protection of domestic markets and facilities from core fraud (that is, essentially manipulative activity) by issuers and their affiliates. ${ }^{70}$ All other antifraud regulation relating to foreign issuer disclosure (for example, state of mind, standing, and privity requirements, the balance between public and private enforcement) would be the domain of the issuer's home country. ${ }^{71}$ Of course, we would want to control domestic selling activity (especially brokerdealer recommendations) to assure that the risks of foreign investment created by this system of regulatory deference are understood by investors. ${ }^{72}$

\section{Conclusion}

This proposal sounds radical, but really it is not. ${ }^{73}$ Under this proposal, U.S. law would retain the ability to reach egregious forms of foreign-based fraud that purposefully distort U.S. markets. Beyond that, however, we would simply ask investors to make a risk assessment regarding the quality of foreign securities regulation, aided by broker-dealers and investment advisers, before buying foreign securities in the secondary markets. That is a regulatory strategy with ample analogies under our current system, which assumes that risk sensitivity usually provides sufficient protection for investors. Indeed, regulatory risk assessment is already a significant part of investing in foreign securities given the alien forms of foreign corporate law that operate as the only direct safeguard against those forms of fiduciary misconduct that cannot be turned into a securities law violation by Schoenbaum-type logic. Those investors uncomfortable with the task can readily turn to mutual funds and other institutions, given their comparative advantage in managing these risks through some combination of analysis and diversification. Insofar as the

Since that time, however, it has evolved into a direct investor protection provision, with clear congressional acquiescence.

70. By "manipulative," I mean conduct intentionally designed to distort the market price. This rule would reach the most egregious forms of fraud, where the defendant is acting to serve its own pecuniary interest through deceptive activity. Here, any conflict among regulatory cultures is unlikely. My suggestion is limited to fraud relating to issuer disclosure, not to the various other forms of fraud that Rule $10 \mathrm{~b}-5$ reaches (for example, face-to-face transactions among investors).

71. Defining "home country" would not always be easy. The most predictable rule would be for the country of incorporation to assume that role. But as a practical matter, the better approach would be to choose the site of the principal place of business (that is, corporate headquarters). The most important consideration is that the choice be a matter of public record and that the supervising country have an effective enforcement capacity with respect to the issuer.

72. In limiting antifraud protection regarding foreign investments, I do not mean to suggest that the U.S. market participants should not seek information about issuers trading in the United States. Just as Rule $12 \mathrm{~g}-3,17$ CFR $\$ 240.12 \mathrm{~g}-3$, does today, foreign issuers trading here would be expected to provide information, and it might be appropriate to impose something of a Rule $15 \mathrm{c} 2$ 11 -style obligation with respect to trading without listing, so that a basic informational file will always be on hand. 17 CFR $\$ 240.15 \mathrm{c} 2-11$. Under some circumstances, it might be appropriate to delist or suspend trading in issues about which inadequate information is available. This regulatory scheme would impose very limited burdens on foreign issuers.

73. Interestingly, this approach would essentially create a conduct-test type emphasis with regard to extraterritorial jurisdiction, since the focus would be on the issuer's disclosure rather than the recipient of the information. 
market for a particular foreign security operates efficiently, moreover, the usefulness of independent analysis is obviated in any event.

In this stark setting, the predictability of the law would be great, and the economic incentives would be strong for each country to build what investors perceive as an efficient system of antifraud protection. ${ }^{74}$ Opportunities for regulatory free-riding would diminish, and the resulting diversity would produce regulatory competition of the most beneficial sort. Moreover, there would be a competitive advantage: much of the disincentive of seeking listing or inclusion on U.S. markets would disappear.

Probably the strongest objection to such a step would come from U.S. issuers, which would remain subject to the more stringent U.S. antifraud regime while foreign counterparts traded in the same markets would not. ${ }^{75}$ To this objection there are two responses. First, disparity already exists in corporate regulation; this step would make only an incremental distinction that follows a pre-existing logic. ${ }^{76}$ Second, a disadvantage would arise only to the extent that investors choose not to compensate by valuing U.S. securities relatively more highly because of the more aggressive regulatory regime. And if they do not, there is a serious flaw in our regulatory ideology. If that is the case, the proper response is to revise the domestic regulatory scheme rather than insist on its world-wide export.

I put forth this suggestion more in the spirit of provocation, of course, than realism. While the trade-offs from a more radical posture of restraint are not unappealing, it asks much of a legal system to renounce future claims that, in specific instances, would provide remedies for U.S. investors. Broad potential jurisdiction is a hallmark of our tradition of securities regulation. ${ }^{77}$ In the end, however, we should at least appreciate the costs associated with that tradition as applied to the international setting. Absent change, we will be subsidizing far more than our fair share of regulatory responsibility, and making clear that notwithstanding calls for harmony and cooperation, we know far better than our neighbors what the law ought to be.

74. The SEC could play a role in gathering and publicizing information about various countries' regulation and legal systems, which could itself have a positive "sunlight" effect on other countries" behavior.

75. This is a concern today with respect to deciding what forms of mandatory disclosure should be imposed on foreign issuers listed on an exchange or included in NASDAQ. The concern would be far more serious were we to say that foreign issuers could compete directly for funds in the United States without the antifraud provisions of the Securities Act of 1933 being available to investors injured by false or misleading prospectuses and registration statements. That, however, is not my suggestion.

76. On the relationship between extraterritorial application of the securities laws and choice of law in corporate matters, see Arthur R. Pinto, The Internationalization of the Hostile Takeover Market: Its Implications for Choice of Law in Corporate and Securities Law, 16 Brooklyn J Intl L 55 (1990). Indeed, the current system no doubt creates a competitive advantage for U.S. companies, since they have much more efficient access to U.S. legal guidance than do their foreign counterparts.

77. See Donald C. Langevoort, The SEC as a Bureaucracy: Public Choice, Institutional Rhetoric, and the Process of Policy Formulation, 47 Wash \& Lee L Rev 527, 530-31 (1990) (noting SEC staff reluctance to some collective valuation. 
.

. 